\title{
DIAGENESIS IN SUBRECENT MARINE SEDIMENTS IN THE EASTERN SCHELDT, SOUTHWEST NETHERLANDS
}

\author{
O. OENEMA* \\ Institute of Earth Sciences, University of Utrecht, P.O. Box 80.021, 3508 TA UTRECHT, The Netherlands
}

\begin{abstract}
The diagenesis in fine-grained sediments from a 300 to 400 -years-old Dunkirk deposit, exposed on the intertidal flat, was studied at a site in the Eastern Scheldt. A new in situ pore water sampling technique that allowed repeated sampling at exactly the same place was used to monitor the seasonal fluctuations in interstitial water composition.

Concentrations of organic carbon (1.5 to $2 \%)$, nitrogen $(\mathrm{C} / \mathrm{N}=19)$, phosphorus $\left(500 \mu \mathrm{g} \cdot \mathrm{g}^{-1}\right)$ and manganese $\left(250 \mu \mathrm{g} \cdot \mathrm{g}^{-1}\right)$ in the subrecent anoxic sediments were low, probably because they had already been depleted during earlier stages of diagenesis. Rates of organic carbon mineralization by sulphate reduction $\left(0.1 \mathrm{Mole} \cdot \mathrm{m}^{-2} \cdot \mathrm{y}^{-1}\right)$ and rates of nutrient regeneration were 1 to 2 orders of magnitude lower than in recent finegrained sediments elsewhere in the Eastern Scheldt.

Pore water $\mathrm{NH}_{4}^{+}$and $\mathrm{\Sigma PO}_{4}$ concentrations were controlled by mineralization, uptake by Zostera noltii and sediment-seawater exchange. During the summer the uptake exceeded the mineralization rate at 0 to $5 \mathrm{~cm}$. Mineralization and diffusional processes dominated the changes in the $\mathrm{NH}_{4}^{+}$and $\mathrm{\Sigma PO}_{4}$ profiles in the other seasons.

Dissolved manganese and iron concentrations showed a typical subsurface maximum at 0 to 3 $\mathrm{cm}$, and low $(<5 \mu$ Mole) concentrations below this depth. Dissolved iron concentrations were probably controlled by the solubility of iron sulphides, and manganese probably by the solubility of Mn, Ca-carbonate.
\end{abstract}

\section{INTRODUCTION}

Before 1986, approximately 0.1 to $0.3 \mathrm{Tg}$ of finegrained sediment (silt + clay) accumulated annualy in sheltered places in the Eastern Scheldt, a tidal inlet in the southwest Netherlands (OENEMA, 1988). This sediment was a mixture of mainly quaternary marine deposits of marine origin, recent algal detritus and river-borne suspended material. The subrecent quaternary deposits locally outcrop in the Eastern Scheldt because of the scouring and deepening of tidal channels and the erosion of salt marshes and tidal flats during the last few centuries (VAN DEN BERG, 1986).

The accreting fine-grained sediments in the Eastern Scheldt are rapidly supplied with new, reactive material. Mineralization of organic matter through sulphate reduction is a dominant diagenetic process in these sediments, supporting high fluxes of $\mathrm{C}, \mathrm{N}, \mathrm{P}, \mathrm{Si}$ and $\mathrm{Mn}$ from the sediments to the overlying water (OENEMA, 1988). In contrast, the subrecent sediments exposed on tidal flats and in tidal channels have lost their most reactive surface layers due to erosion. Initial diagenesis since its deposition several centuries ago will also have decreased the reactivity of these subrecent sediments (BERNER, 1980).

Within the context of studies on the early diagenesis in anoxic fine-grained sediment, we made measurements of sedimentation rates and of the composition of sediments and their pore waters, to assess the role of the sedimentary environment in the carbon and nutrient cycles of the Eastern Scheldt. This paper reports the investigations on the diagnesis in the subrecent marine sediments. 
Acknowledgements.-I would like to express my appreciation to Martinus Vranken and Hein Craanen for assistance with the sediment analyses. Jan Drenth assisted with the design and construction of the interstitial water sampler. Interstitial water analyses were carried out at the laboratory of Rijkswaterstaat, Tidal Waters Division, Middelburg. Comments of Dr. Bert van Eck on an earlier version significantly improved the clarity of this manuscript. The critical review of Dr. M.M. Rutgers van der Loeff is highly appreciated. This work was supported by the Delta Department of the Ministry of Transport and Public Works.

\section{METHODS}

\subsection{STUDY SITE}

The Eastern Scheldt is a tidal inlet with a total surface area of $450 \mathrm{~km}^{2}$. Approximately $30 \%$ of the area consists of intertidal flats. The tide range was 3.0 to $3.5 \mathrm{~m}$ and the tidal volume 1100 million $\mathrm{m}^{3}$ before the recently completed Storm Surge Barrier and Compartment dams in 1986-1987 (KNOESTER et al., 1984). The fresh water and river-borne suspended matter inputs were relatively small (STORTELDER et al., 1984).

The study site was located on an intertidal flat in the Zandkreek (Fig. 1), where 20 to $30 \%$ of the surface area is covered by subrecent clayey deposits. These bluish-grey deposits (Revised Standard Soil Color Charts) of low porosity $\left(0.55-0.65 \mathrm{~cm}^{3} \mathrm{~cm}^{-3}\right)$ are remnants of eroded salt marshes, which probably began to form in the 16th and 17th centuries, according to historic maps (DE BRUIN \& WILDEROM, 1961). No precise data for the formation and the erosion rate of these marshes are available. Topographic maps of 1856, 1902 (map 48) and 1933 (maps 617, 618, 637 and 638) indicate that the former marshes in the Zandkreek were almost completely eroded between 1856 and 1933. Since then little or no sedimentation has occurred at the study site. These subrecent sediments are easily distinguished from the highly unconsolidated (porosity is 0.70 to 0.85 ) dark grey muds of the rapidly accreting fine-grained sediments in abandoned channels and mussel plots in the Zandkreek and elsewhere in the Eastern Scheldt (OENEMA, 1988). Like most of the sheltered locations with clayey sediments in the Eastern Scheldt, the surface of the study site was covered in summer with a dense growth of eelgrass, Zostera noltii (NIENHUIS \& DAEMEN, 1985).

\subsection{SEDIMENT ANALYSIS}

Sections of 2 to $10 \mathrm{~cm}$ of a $1 \mathrm{~m}$ deep sediment core (i.d. $10 \mathrm{~cm}$ ) were freeze-dried immediately after sampling. All further sediment analyses, except for the determination of the grain-size distribution, were carried out on powdered samples. A summary of the methods used is given in Table 1.

\subsection{PORE-WATER ANALYSIS}

-The sampler. Pore water was sampled by in situ dialysis (e.g. CARRIGAN, 1984; HeSSLEIN, 1976; HOWES, 1985), to avoid any artifacts of oxidation and temperature which might have occurred if squeezing or centrifuging techniques had been used. The sampler (Fig. 2a), a modified and extended version of the sampler described by HESSLEIN (1976), allowed

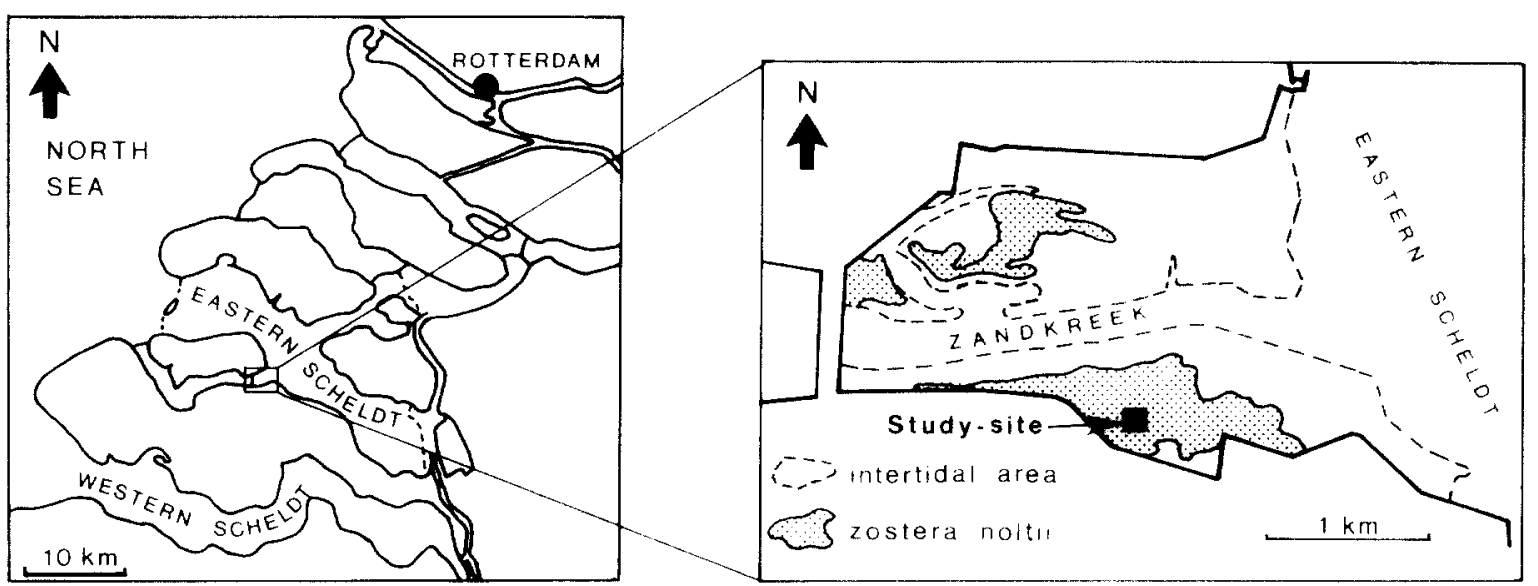

Fig. 1. The Zandkreek study-site in the Eastern Scheldt, with distribution of Zostera noltii in 1984 according to data of D.J. de Jong. 
TABLE 1

Analytical methods for sediment analysis.

\section{Porosity:}

Grain-size distribution:

Loss on ignition:

Major elements:

Organic $\mathrm{C}$ :

Total N:

Calcite:

Fe, Mn oxyhydroxides:

Pyrite-iron:

Phosphates: from weight loss of known sediment volumes.

pipette method, after pre-treatment with $\mathrm{H}_{2} \mathrm{O}_{2}$ and $\mathrm{HCl}$.

ignition at $950^{\circ} \mathrm{C}$.

determination of $\mathrm{Si}, \mathrm{Al}, \mathrm{Fe}, \mathrm{Ca}, \mathrm{Mg}, \mathrm{K}, \mathrm{Mn}$ and $\mathrm{P}$ by XRF after fusion of $0.5 \mathrm{~g}$ of ignited sediment with $5 \mathrm{~g}$ Spectroflux type 1100 (Johnson Matthey Chemicals, England).

wet oxidation with $\mathrm{K}_{2} \mathrm{Cr}_{2} \mathrm{O}_{7}$ and $\mathrm{H}_{2} \mathrm{SO}_{4}$ (PAGE et al., 1982).

titrimetric, after digestion with $\mathrm{H}_{2} \mathrm{SO}_{4}$ and $\mathrm{Se}$ (PAGE et al., 1982).

acid dissolution and determination of the volume of liberated $\mathrm{CO}_{2}$ (PAGE et al., 1982).

extraction with $\mathrm{NH}_{4}$-oxalate $(1 \mathrm{M}, \mathrm{pH} 3)$; determination of iron and manganese with AAS (SCHWERTMANN, 1964).

selective dissolution with $\mathrm{H}_{2} \mathrm{SO}_{4}(96 \%), \mathrm{HF}(48 \%)$ and $\mathrm{HNO}_{3}(70 \%)$ (BEGHEYN et al., 1978); determination of iron with AAS.

extraction scheme of HIELTJES \& LYKLEMA (1980)

-exchangeable and carbonate bound-P: $1 \mathrm{M} \mathrm{NH}_{4} \mathrm{Cl}$

- Fe and $\mathrm{Al}$ oxyhydroxide bound-P: $0.1 \mathrm{M} \mathrm{NaOH}$

- $\mathrm{Ca}$ bound-P: $0.5 \mathrm{M} \mathrm{HCl}$
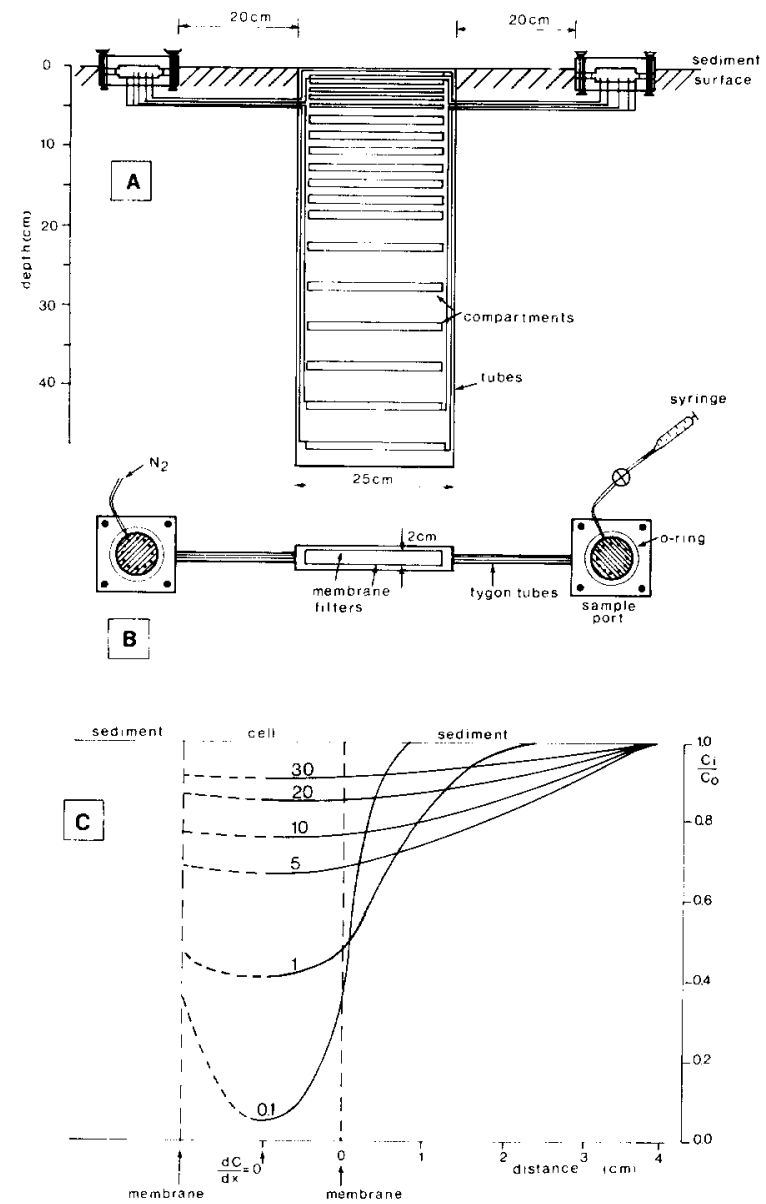

Fig. 2. The pore-water sampler: (A) cross-section in the sediment, (B) view from the top during sampling, and (C) development of equilibrium in the dialysis cell after 0.1 to 30 days (see text) repeated sampling of pore water at exactly the same location. It had 5 compartments of $20 \mathrm{~cm}^{3}$ each in the top $5 \mathrm{~cm}$, and $40 \mathrm{~cm}^{3}$ compartments at 1 to $5 \mathrm{~cm}$ depth intervals below. Both sides of the 2-cm-thick (PVC) sampler contained a biologically inert acrylic copolymer membrane filter (Versapor-200; Gelman Sciences) with a pore-size of $0.2 \mu \mathrm{m}$, attached to the sampler by a thin $(1.5 \mathrm{~mm})$ PVC sheet with notches at the level of each compartment. This membrane filter was so strong that after a period of two years in several types of sediments in the Eastern Scheldt, no visible degradation of the membrane filters was observed. Each compartment was connected by to tygon (PVC, Norton, Belgium) tubes (i.d. $0.8 \mathrm{~mm}$; o.d. $4.0 \mathrm{~mm}$ ) to two sample ports at the surface, one with the bottom of each compartment and the other with the top. The sampler was inserted in the sediment at a slight angle ( 1 to $2^{\circ}$ to the vertical) and remained there permanently. The depth of the upper sample compartment varied irregularly between 0 to $0.5 \mathrm{~cm}$ depth in the sediment during the sampling period, due to temporal sedimentation and erosion of fine sand and silt.

-Sampling and analysis. Samples were withdrawn from the compartments by drawing the "pore water" through one sample port into a syringe and pumping nitrogen gas into the compartment via the second port (Fig. 2b). After sampling, all compartments were immediately refilled with filtered $(0.2 \mu \mathrm{m})$, deoxygenated Eastern Scheldt water. The connections between the compartments and sample ports, and the slight inclination of the sampler in the sediment, allowed all nitrogen gas to escape during this replenishment. 
Three successive samples with a total volume of about $15 \mathrm{~cm}^{3}$ were drawn from each compartment. The sample volumes were calculated from the weight differences of the syringes before and after sampling. The first 1 to $2 \mathrm{~cm}^{3}$ were always discarded via a 3-way valve (Fig. 2b). A 0.5 to $1.5 \mathrm{~cm}^{3}$ portion was sucked into a syringe, prefilled with $2 \mathrm{~cm}^{3} \mathrm{Zn}$-acetate (2\%) and $0.5 \mathrm{~cm}^{3} 1 \mathrm{M} \mathrm{NaOH}$, for dissolved sulphide (IS) determination. A 2 to $4 \mathrm{~cm}^{3}$ portion went into a syringe prefilled with $5 \mathrm{~cm}^{3} 0.1 \mathrm{M} \mathrm{H}_{2} \mathrm{SO}_{4}$ for the determination of $\mathrm{Fe}^{2+}$ and $\mathrm{Mn}^{2+}$. Another 8 to 12 $\mathrm{cm}^{3}$ went into an empty syringe for the determination of $\mathrm{pH}, \mathrm{Cl}^{-}, \mathrm{SO}_{4}^{2-}$, total inorganic carbon $\left(\mathrm{ZCO}_{2}\right), \mathrm{NH}_{4}^{+}, \mathrm{IPO}_{4}$, and dissolved reactive silica $\left(\mathrm{H}_{4} \mathrm{SiO}_{4}\right)$. All samples were stored at $4^{\circ} \mathrm{C}$ and analysed within $36 \mathrm{~h}$. The whole sampling procedure took approximately $2 \mathrm{~h}$. Extreme care was taken not to disturb the sediment within $0.5 \mathrm{~m}$ of the sampler.

The analyses for $\mathrm{Cl}^{-}, \mathrm{SO}_{4}^{2-}, \mathrm{\Sigma CO}_{2}, \mathrm{NH}_{4}^{+}, \mathrm{\Sigma PO}_{4}$, $\mathrm{H}_{4} \mathrm{SiO}_{4}$, Fe and $\mathrm{Mn}$ were done by routine autoanalyser techniques. Dissolved $\Sigma S$ was measured on a Perkin Elmer $550 \mathrm{~S}$ spectrophotometer $(670 \mathrm{~nm})$. A summary of the analytical methods is given in Table 2.

- Sampling frequency. The equilibration time of the solution in the sampler was calculated according to Fick's second law and verified experimentally. When the sampler, filled with distilled water, was placed in the clayey sediment for 19 days, the $\mathrm{Cl}^{-}$and $\mathrm{SO}_{4}^{2-}$ concentrations in the compartments were still only 90 to $95 \%$ of the concentrations in pore water squeezed from a core taken in the vicinity of the sampler. Complete equilibrium, i.e. less than $4 \%$ difference between $\mathrm{Cl}^{-}$and $\mathrm{SO}_{4}^{2-}$ concentrations in the sampler and those in the pore waters squeezed from a core taken nearby, was attained after $\geq 25$ days.

Calculations, based on the concept of one- dimensional diffusion from a constant source (e.g. KEPKAY et al., 1981), confirmed these results. Fick's second law holds for the dialysis cell:

$$
\frac{d C_{1}}{d t}=D \frac{d^{2} C_{1}}{d x^{2}}
$$

and the sediment:

$$
\frac{d C_{2}}{d t}=D_{s} \frac{d^{2} C_{2}}{d x^{2}}
$$

where $C_{1}, C_{2}=$ concentrations of ions in cell and sediment, respectively,

$D=$ diffusion coefficient in seawater $\left(\mathrm{cm}^{2} \cdot \mathrm{s}^{-1}\right)$,

$D_{S}=D \Phi^{n-1}=$ diffusion coefficient in sediment corrected for porosity and tortuosity $(n \approx 2$ for sediments with $\Phi<0.7$; ULLMAN \& ALLER, 1982),

$\Phi=$ porosity

$x=$ distance $(\mathrm{cm})$,

$t=$ time (s)

The diffusive fluxes match at the membrane so that at this site for $t>0$

$$
D \frac{d C_{1}}{d x}=\Phi D_{s} \frac{d C_{2}}{d x}
$$

The partial differential equations (1) and (2) were solved numerically by Gear's method (DEW \& WALSH, 1981) for the following conditions:

initial conditions:

$C_{1}=0$ (distilled water in the cell),

$C_{2}=C_{o}$ (equilibrium concentration in the sediment),

boundary conditions:

\section{TABLE 2}

Analytical methods for pore-water analyses.

\begin{tabular}{ll}
\hline $\mathrm{pH}$ & with a micro-electrode within $3 \mathrm{~h}$ of sampling \\
$\Sigma \mathrm{S}$ & methylene-blue (GILBOA-BARBER, 1976) \\
$\mathrm{Cl}^{-}$ & mercury thiocyanate (ZALL et al., 1956) \\
$\mathrm{SO}_{4}^{2-}$ & methylthymol blue (MERKS \& SINKE, 1981) \\
$\mathrm{SO}_{2}$ & sulfuric acid-gas membrane-phenolphtalein (GRASSHOFF \& HANSEN, 1979) \\
$\mathrm{NH}_{4}^{+}$ & sodium salicylate-nitro-prusside-hypochiorite (TELLOW \& WiLSON, 1964) \\
$\mathrm{NO}_{3}^{-}+\mathrm{NO}_{2}^{-}$ & $\begin{array}{l}\text { sulfanilamide-N- (1 naphtylethylene diamine) dihydrochloride, after cadmium reduction } \\
\text { (ARMSTRONG et al., 1967) }\end{array}$ \\
$\mathrm{\Sigma PO}_{4}$ & molybdate-ascorbic acid (MURPHY \& RILEY, 1962) \\
$\mathrm{H}_{4} \mathrm{SiO}_{4}$ & molybdate-ascorbic acid-oxalic acid (BREWER \& RILEY, 1966) \\
$\mathrm{Fe}^{2+}$ & $2,4,6,-$ tripyridyl-(2)-1, 3, 5,-triazine-hydroxylamine (HENRIKSEN, 1967) \\
$\mathrm{Mn}^{2+}$ & formaldoxime (HENRIKSEN, 1966) \\
\hline
\end{tabular}


$\frac{d C_{1}}{d x}=0$ (in the centre of the cell),

$C_{2}=C_{o}$ (in the sediment, at distance $z$ from the cell membrane).

An example of these calculations is shown in Fig. 2c for $\mathrm{z}=4 \mathrm{~cm}, D\left(\mathrm{Cl}^{-}\right)=1.6^{*} 10^{-5} \mathrm{~cm}^{2} \cdot \mathrm{s}^{-1}$ and $\Phi=0.6$. After 30 days the concentration in the dialysis cell was $91 \%$ of the equilibrium concentration $C_{o}$ in the sediment. Incomplete equilibration in the cell compartments after 30 days was calculated if the distance $z$ of the second boundary condition exceeded $2 \mathrm{~cm}$. Thus, when the second boundary condition held for $z=\infty$, the final concentration in the compartments was only $84 \%$ of $C_{o}$ after 30 days; for $z=1.5$ $\mathrm{cm}$ equilibrium was attained after 21 days.

Comparison of results from these calculations with those obtained experimentally indicated that twoand three-dimensionsal diffusion played an important role in the replenishment of the ion-depleted pore waters in the sediment adjacent to the sampler. Production of ions in the sediment by, for example, the oxidation of organic matter will accelerate the equilibration process in the cell. On the basis of these considerations the sampling frequency was set at once per 1 to 2 months, to attain >95\% equilibrium in the dialysis cells, also after repeated samplings.

\section{RESULTS AND DISCUSSION}

Results of the sediment analyses are shown in Table 3 and Fig. 3. Seasonal variations in the pore-water composition are indicated in Figs 4 to 8 .

\subsection{CALCULATION OF THE SEDIMENT DIFFUSIVITY}

The chlorosity (Fig. 4a) of the surface layers ( 0 to 20
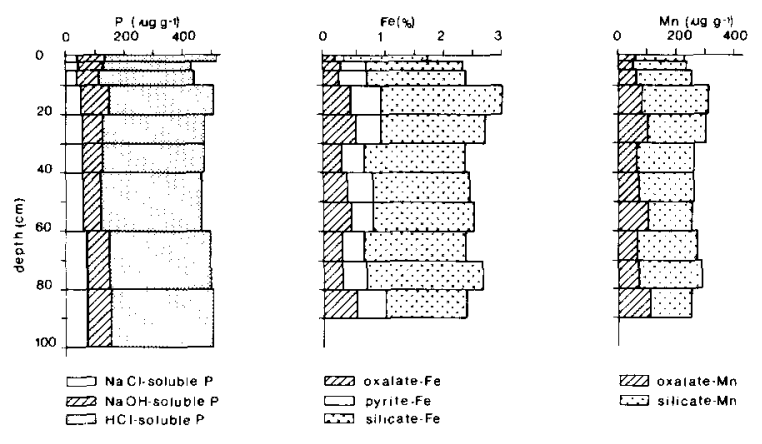

Fig. 3. The speciation of phosphorus, iron and manganese in the sediment.

$\mathrm{cm}$ ) responded to seasonal salinity variations in the Eastern Scheldt. These variations reflect real seasonal changes, because the sampler remained at exactly the same location throughout the study. This is a major advantage of the present in situ pore-water sampling technique for studying seasonal changes, because spatial variation does not obscure them.

The range of chlorosities (15 to $18 \mathrm{~g} \cdot \mathrm{dm}^{-3}$ ) in the surface layers exceeded the mean seasonal range in the overlying Eastern Scheldt water (STORTELDER et al., 1984) by a factor of almost 2. A part of this increased variation may have been caused by brackish-water ( 8 to $13 \mathrm{~g} \mathrm{Cl}^{-} \cdot \mathrm{dm}^{-3}$ ) discharges from the Zandkreek sluices in autumn. Infiltration of rainwater into the sediment in winter and evaporation of pore water from the surface layers during low tides in summer may also play a role. At depths greater than about 15 to $20 \mathrm{~cm}$ in the sediment, the chloride concentration converged to a seasonally averaged chlorosity of $16.4 \mathrm{~g} \cdot \mathrm{dm}^{-3}$. The thickness $(L)$ of the

TABLE 3

Sediment composition at different depths. LOI=Loss on ignition.

\begin{tabular}{|c|c|c|c|c|c|c|c|c|c|c|c|c|}
\hline $\begin{array}{l}\text { depth } \\
\mathrm{cm}\end{array}$ & porosity & $\begin{array}{l}\text { clay } \\
\text { (\%) }\end{array}$ & $\begin{array}{c}\text { clay+ silt } \\
(\%)\end{array}$ & $\underset{(\%)}{\operatorname{org} . C}$ & $\begin{array}{c}\text { N-tot } \\
(\%)\end{array}$ & $\begin{array}{l}\angle O I \\
(\%)\end{array}$ & $\begin{array}{c}\mathrm{CaCO}_{3} \\
(\%)\end{array}$ & $\begin{array}{c}S i \\
(\%)\end{array}$ & $\begin{array}{c}A I \\
(\%)\end{array}$ & $\begin{array}{c}\mathrm{Ca} \\
(\%)\end{array}$ & $\begin{array}{l}M g \\
(\%)\end{array}$ & $\begin{array}{c}K \\
(\%)\end{array}$ \\
\hline $0-2$ & 0.65 & 11 & 33 & 1.4 & 0.08 & 9.8 & 9.8 & 31.8 & 3.09 & 4.07 & 0.53 & 1.35 \\
\hline 2- 5 & 0.60 & 27 & 59 & 2.1 & 0.10 & 13.4 & 14.1 & 28.1 & 4.40 & 5.80 & 0.85 & 1.59 \\
\hline $\begin{array}{r}5-10 \\
10-20\end{array}$ & $\begin{array}{l}0.63 \\
0.60\end{array}$ & $\begin{array}{l}24 \\
35\end{array}$ & $\begin{array}{l}62 \\
83\end{array}$ & $\begin{array}{l}1.8 \\
2.3\end{array}$ & $\begin{array}{l}0.09 \\
0.14\end{array}$ & $\begin{array}{l}12.7 \\
16.2\end{array}$ & $\begin{array}{l}14.2 \\
15.1\end{array}$ & $\begin{array}{l}28.6 \\
25.0\end{array}$ & $\begin{array}{l}4.17 \\
5.35\end{array}$ & $\begin{array}{l}5.71 \\
6.82\end{array}$ & $\begin{array}{l}0.82 \\
1.07\end{array}$ & $\begin{array}{l}1.51 \\
1.71\end{array}$ \\
\hline $20-30$ & 0.60 & 34 & 78 & 2.0 & 0.11 & 14.5 & 15.2 & 26.9 & 4.80 & 6.40 & 0.94 & 1.59 \\
\hline $30-40$ & 0.59 & 19 & 65 & 1.9 & 0.09 & 12.6 & 14.2 & 28.7 & 4.27 & 5.86 & 0.88 & 1.49 \\
\hline $40-50$ & 0.55 & 26 & 71 & 1.8 & 0.10 & 13.9 & 15.1 & 27.7 & 4.48 & 6.11 & 0.92 & 1.49 \\
\hline $50-60$ & 0.54 & 22 & 63 & 1.8 & 0.09 & 13.6 & 15.1 & 28.2 & 4.34 & 6.22 & 0.91 & 1.46 \\
\hline $60-70$ & 0.56 & 25 & 61 & 1.9 & 0.10 & 14.0 & 15.7 & 27.8 & 4.37 & 6.27 & 0.88 & 1.46 \\
\hline $70-80$ & 0.59 & 25 & 71 & 2.0 & 0.10 & 14.1 & 15.3 & 27.6 & 4.54 & 6.25 & 0.91 & 1.54 \\
\hline $80-90$ & 0.54 & 27 & 66 & 1.9 & 0.11 & 13.5 & 13.8 & 28.3 & 4.41 & 6.07 & 0.98 & 1.56 \\
\hline
\end{tabular}



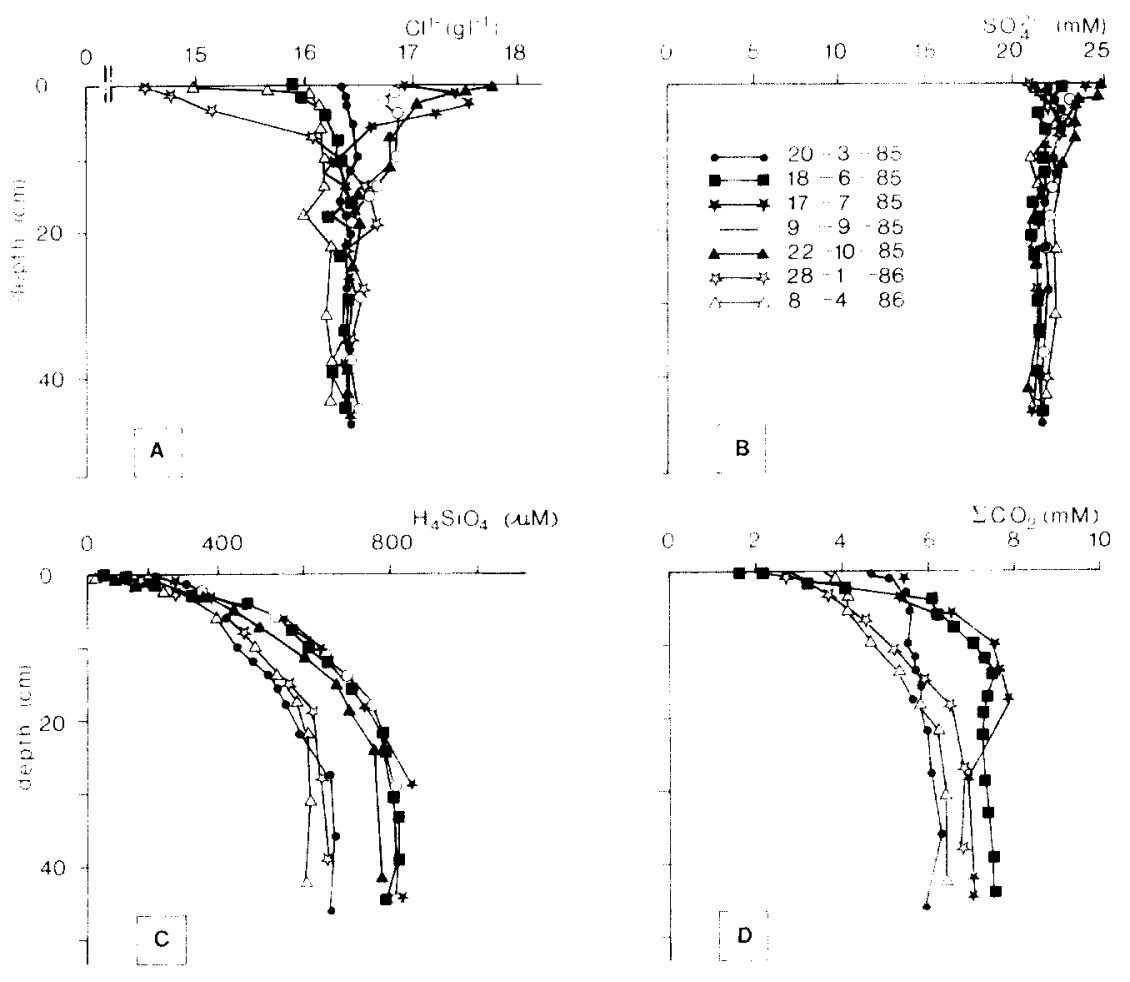

Fig. 4. Seasonal variation in pore-water concentrations of (A) chloride, (B) sulphate, (C) reactive silica, and (D) total inorganic carbon concentrations.

surface layer responding to the diffusive transport from the overlying water is related to the sediment diffusion coefficient according to $L=\left(D_{s} t\right)^{0.5}$. If it is assumed that the chloride concentration in the superficial layer fluctuates seasonally about a mean value, it follows that for a "damping depth" $L=15$ to $20 \mathrm{~cm}$, the apparent sediment diffusivity of $\mathrm{Cl}^{-}$is 225 to $400 \mathrm{~cm}^{2} \cdot \mathrm{y}^{-1}$. Application of the harmonic diffusion/advection model of HOLDREN et al. (1975) and LORD \& CHURCH (1983) predicted 4 of the 7 observed $\mathrm{Cl}^{-}$profiles to within $3 \%$, using a sediment diffusion coefficient for $\mathrm{Cl}^{-}$of $300 \mathrm{~cm}^{2} \cdot \mathrm{y}^{-1}$. An increase or decrease in the sediment diffusion coefficient by a factor of $\mathbf{1 . 5}$ gave significantly greater deviations from the observed profiles at depth of 5 to $20 \mathrm{~cm}$. The predicted profiles of October, March and June gave a somewhat wider variation (up to $8 \%$ in the upper 3 $\mathrm{cm}$ ), suggesting that some discrete, temporal events also affect the variation of $\mathrm{Cl}^{-}$concentrations in the surface layers. This limits the application of the sinusoidal diffusion model for the estimation of the sediment diffusion coefficient at this site, and therefore the results have to be interpreted cautiously.

A comparable value for the sediment diffusivity was calculated from the molecular diffusion coefficient, corrected for porosity and tortuosity according to the formula:

$$
D_{S}=D \Phi^{n-1}=270 \mathrm{~cm}^{2} \cdot \mathrm{y}^{-1}
$$

where $D=440 \mathrm{~cm}^{2} \cdot \mathrm{y}^{-1}$ (diffusion coefficient of $\mathrm{Cl}^{-}$ adjusted to a mean annual temperature of $11^{\circ} \mathrm{C}(\mathrm{LI} \&$ GREGORY, 1974), and $n=2$ (ULLMAN \& ALLER, 1982). These results suggest that the solute transport in the pore waters takes place mainly by diffusion. Wave action during rough weather conditions may temporarily increase the diffusion coefficient in the surface layer (e.g. RUTGERS VAN DER LOEFF, 1981), but apparently have no great effect on the mean annual diffusion coefficient. Effects of tides are also of minor influence regarding the relatively quiescent geographical location of the study site at present, the small hydraulic gradient during low tide $\quad<2$ $\mathrm{m} \cdot \mathrm{km}^{-1}$ ) and the clayey composition of the sediment (Table 3). Effects of bioturbation and irrigation are restricted to the upper $2 \mathrm{~cm}$, where high densities (100 to 200 per $\mathrm{m}^{2}$ ) of cockles, Cerastoderma edule, were found. No deeper-burrowing fauna was observed at the study site (unpublished results). 


\subsection{ORGANIC MATTER OXIDATION}

Organic carbon concentrations (1.5 to $2 \%$ ) were related to the clay content $\left(R^{2}=0.76\right)$ and were 1 to 2 times smaller than in the recent fine-grained sediments elsewhere in the Eastern Scheldt (OENEMA, 1988). The mineralization of metabolizable organic matter has proceeded continuously in the sediment since its deposition som 3 to 4 centuries ago, and has decreased the organic carbon-clay ratio.

The low Eh $(-150$ to $-200 \mathrm{mV})$ below a depth of 1.5 $\mathrm{cm}$ and the low $\mathrm{NO}_{3}^{-}$concentrations $(<0.5 \mu \mathrm{Mole})$ at all depths suggest that the reduction of $\mathrm{O}_{2}$ and $\mathrm{NO}_{3}^{-}$ by organic matter oxidation was confined to the superficial sediment. Sulphate was the major electron acceptor below a depth of 0.5 to $1.5 \mathrm{~cm}$. The bacterial sulphate reduction caused a slight decrease in the sulphate concentration in the top 20cm (Fig. 4b).

A rough estimate of the sulphate reduction rate was made by calculating the diffusive sulphate flux into the sediment. First, exponential functions of the type:

$$
C_{x}=\left(C_{o}-C_{\infty}\right) \exp (-b x)+C_{\infty}
$$

were fitted to measured pore-water sulphate profiles, normalized to an average chlorosity of $16.4 \mathrm{~g} \cdot \mathrm{dm}^{-3}$, to estimate $C_{o}, C_{\infty}$ and the attenuation coefficient $b$. An exponentially decreasing $\mathrm{SO}_{4}^{2-}$ concentration with depth gave better fits than a linearly decreasing sulphate concentration, as has been shown (e.g. BERNER, 1980) for many marine sediments. However, the attenuation coefficient $b$ is only a parameter fit; it has no mechanistic meaning in this particular case. Next, the flux was calculated from Fick's law:

$$
F=\left.\Phi D_{s} \frac{d C}{d x}\right|_{\mathrm{x}=0}=\Phi D_{s} b\left(C_{o}-C_{\infty}\right)
$$

where $\mathrm{F}=\mathrm{SO}_{4}^{2-}$ flux $\left(\mu\right.$ Mole $\left.\cdot \mathrm{cm}^{-2} \cdot \mathrm{d}^{-1}\right)$, $\mathrm{C}_{0}=\mathrm{SO}_{4}^{2-}$ concentration at zero depth $\mu$ Mole $\cdot \mathrm{cm}^{-3}$ ), $\mathrm{C}_{\infty}=\mathrm{SO}_{4}^{2-}$ concentration below $20 \mathrm{~cm}$ $\left(\mu\right.$ Mole $\left.\cdot \mathrm{cm}^{-3}\right)$, and

$\mathrm{b}=$ attenuation coefficient $\left(\mathrm{cm}^{-1}\right)$.

Mean porosity and tortuosity-corrected $\mathrm{SO}_{4}^{2-}$ diffusion coefficients were calculated from (4) and data from the literature (LI \& GREGORY, 1974): $0.5 \cdot 10^{-5} \mathrm{~cm}^{2} \cdot \mathrm{s}^{-1}$ in summer (mean temperature $15.5^{\circ} \mathrm{C}$ ) and $0.36 \cdot 10^{-5} \mathrm{~cm}^{2} \cdot \mathrm{s}^{-1}$ in winter $\left(\right.$ at $\left.6^{\circ} \mathrm{C}\right)$. The best fits of (5) to the measured $\mathrm{SO}_{4}^{2-}$ profiles were obtained with an attenuation coefficient $b$ of 0.10 to $0.15 \mathrm{~cm}^{-1}$ and with $\left(C_{o}-C_{\infty}\right)=0.5$ to 2.0 $\mu$ Mole $\cdot \mathrm{cm}^{-3}$. The calculated sulphate reduction rate varied from 230 to $680 \mu$ Mole $\cdot \mathrm{m}^{-2} \cdot \mathrm{d}^{-1}$ in summer to 50 to $160 \mu$ Mole $\cdot \mathrm{m}^{-2} \cdot d^{-1}$ in winter. These rates are 1 to 2 orders of magnitude lower than those measured in other near-shore marine sediments (GOLDHABER et al., 1977; JøRGENSEN, 1977; BERNER \& WESTRICH, 1985). Sulphate reduction rates in recent marine deposits in the Eastern Scheldt were also 10 to 100 times larger (OENEMA, 1988).

Similar calculations were made for $\mathrm{\Sigma CO}_{2}$. Dissolved $\mathrm{\Sigma CO}_{2}$ increased from about $2 \mathrm{mMole}$ in the surface layer to about 6 to $8 \mathrm{mMole}$ at depths $>15 \mathrm{~cm}$ (Fig. 4d) due to organic matter oxidation. Most of the $\mathrm{\Sigma CO}_{2}$ is present as $\mathrm{HCO}_{3}^{-}$at a $\mathrm{pH}$ varying from 7.2 to 7.4 in the sediment (STUMM \& MORGAN, 1981). Therefore, the sediment diffusivity of bicarbonate ( $L I$ \& GREGORY, 1974; (4)) was adopted in the following calculations: $0.55 \cdot 10^{-5} \mathrm{~cm}^{-2} \cdot \mathrm{s}^{-1}$ in summer and $0.4 \cdot 10^{-5} \mathrm{~cm}^{-2} \cdot \mathrm{s}^{-1}$ in winter. The calculated diffusive flux from the sediment (2500 to $3600 \mu \mathrm{Mole} \cdot \mathrm{m}^{-2} \cdot \mathrm{d}^{-1}$ in summer and 800 to $1600 \mu \mathrm{Mole} \cdot \mathrm{m}^{-2} \cdot \mathrm{d}^{-1}$ in winter) exceeded the opposite $\mathrm{SO}_{4}^{2-}$ flux by 5 to 10 times. A $\mathrm{CCO}_{2} / \mathrm{SO}_{4}^{2}-$ flux ratio of minus 5 to 10 is far more than the expected minus 2 inferred stoichiometrically from bacterial sulfate reduction, assuming equal coefficients of molecular diffusion for $\mathrm{HCO}_{3}^{-}$and $\mathrm{SO}_{4}^{2-}$ (e.g. ELDERFIELD et al., 1981a). This large $\mathrm{\Sigma CO}_{2}$ excess relative to the $\mathrm{SO}_{4}^{2-}$ depletion suggests that other sources of $\Sigma \mathrm{CO}_{2}$ are involved than bacterial sulphate reduction alone.

Organic matter oxidation by $\mathrm{O}_{2}$ and $\mathrm{NO}_{3}^{-}$reduction may increase the $\Sigma \mathrm{CO}_{2}$ concentration in the pore water by approximately twice the $\mathrm{O}_{2}$ (250 to 330 $\mu \mathrm{M})$ plus $\mathrm{NO}_{3}^{-}$(0 to $80 \mu \mathrm{M}$ ) concentrations present in the overlying seawater (ELDERFIELD et al., 1981a). Thus, at most 500 to $800 \mu \mathrm{M}$ of the excess $\Sigma \mathrm{CO}_{2}$ in the overlying seawater originates from $\mathrm{O}_{2}$ and $\mathrm{NO}_{3}^{-}$ reduction in the surface sediment. Another minor portion of $\mathrm{\Sigma CO}_{2}$ may come from microbial $\mathrm{Mn}$ and Fe oxihydroxide reduction (S $\varnothing$ RENSEN \& J $\varnothing$ RGENSEN, 1987). The $\mathrm{\Sigma CO}_{2}$ production by $\mathrm{O}_{2}$ and $\mathrm{NO}_{3}^{-}$reduction can explain the large $\mathrm{LCO}^{2}$ excess relative to the $\mathrm{SO}_{4}^{2-}$ depletion in winter pore waters, but not in those of summer. Probably a major source of the $\mathrm{\Sigma CO}_{2}$ excess relative to the $\mathrm{SO}_{2-}^{4}$ depletion in summer is root respiration and oxygen release by Zostera noltii in the sediment (e.g. GLEASON \& ZIEMAN, 1981; SAND-JENSEN et al., 1982). Root respiration increases the $\Sigma \mathrm{CO}_{2}$ concentration in the sediment, and release of $\mathrm{O}_{2}$ by the roots may oxidize sulphides to sulphate. Consequently, the root activity of Zostera noltii may increase the concentrations of both $\mathrm{\Sigma CO}_{2}$ and $\mathrm{SO}_{4}^{2-}$ in the pore water, thereby increasing the ratio of the $\mathrm{\Sigma CO}_{2}$ increase relative to the $\mathrm{SO}_{4}^{2-}$ 
depletion. The possible oxidation of sulphides to sulphate in the rhizosphere also causes an underestimation of the calculated sulphate reduction rate. The calculated rates of 50 to $160 \mu \mathrm{mol} \cdot \mathrm{m}^{-2} \cdot \mathrm{d}^{-1}$ in summer are therefore lower limits. Precipitation of $\mathrm{Mn}$, Ca-carbonates (see below) may have slightly lowered the $\mathrm{\Sigma CO}_{2}$ concentration.

In summary, several diagenetic processes, of which bacterial sulphate reduction, root respiration and sulphide oxidation in the rhizosphere appear to be of prime importance, have modified the $\mathrm{\Sigma CO}_{2}$ and $\mathrm{SO}_{4}^{2-}$ concentrations in the pore waters.

\subsection{NITROGEN AND PHOSPHORUS DIAGENESIS}

A complex seasonal variation in $\mathrm{NH}_{4}^{+}$and $\mathrm{\Sigma PO}_{4}$ concentrations occurred in the pore waters of the surface layers $(0$ to $20 \mathrm{~cm}$ ) (Figs 5 and 6 ). These shortterm variations were caused by nutrient uptake by Zostera noltii in the summer, superimposed on seasonally varying rates of nutrient regeneration and sediment-seawater exchange. Between May and August, the nutrient uptake clearly exceeded the nutrient regeneration at 0 to $5 \mathrm{~cm}$, resulting in very low $\mathrm{SPO}_{4}$ and $\mathrm{NH}_{4}^{+}$concentrations in the superficial sediment. Between September and April the opposite occurred. During the winter (e.g. data of January 1986), the rate of sediment-seawater exchange apparently exceeded the rate of nutrient regeneration, because the $\mathrm{NH}_{4}^{+}$and $\mathrm{\Sigma PO}_{4}$ concentrations in the 0 to $5 \mathrm{~cm}$ depth interval were lower than in autumn.

The total nitrogen and phosphorus uptake by Zostera noltii at the study-site was calculated from the primary production and the elemental $\mathrm{C}: \mathrm{N}: \mathrm{P}$ composition. The total primary production above and below ground at the study site is 100 to $150 \mathrm{~g}$ $\mathrm{C} \cdot \mathrm{m}^{-2} \cdot \mathrm{y}^{-1}$ (NIENHUIS \& DAEMEN, 1985; Daemen, pers. comm.). A mean $C: N: P$ ratio in the shoots (180:15:1) and the roots (210:9:1) was calculated from data of DAEMEN (1979).

If the nutrients were taken up by the roots alone, the mean pore-water $\mathrm{NH}_{4}^{+}$pool ( 3 to $6 \mathrm{mMole} \cdot \mathrm{m}^{-2}$ ) in the upper $10 \mathrm{~cm}$ would have been replenished 150 to 200 times per year to account for the total nitrogen uptake (700 to $\left.1100 \mathrm{mMole} \cdot \mathrm{m}^{-2} \cdot \mathrm{y}^{-1}\right)$. Similar calculations for the total phosphorus uptake (50 to 70 mMole $\cdot \mathrm{m}^{-2} \cdot \mathrm{y}^{-1}$ yield a turnover of 100 to 150 times per year for the pore-water $\mathrm{\Sigma PO}_{4}$ pool. On the assumption that the relative changes of $\mathrm{\Sigma CO}_{2}$, $\mathrm{SO}_{4}^{2-}, \mathrm{NH}_{4}^{+}$and $\Sigma \mathrm{PO}_{4}$ in the pore water follow the REDFIELD et al. (1963) ratio (106:-53:16:1), it can easily be calculated from the estimated sulphate reduction rate (50 to $150 \mathrm{mMole} \cdot \mathrm{m}^{-2} \cdot \mathrm{y}^{-1}$, or from the total $\mathrm{\Sigma CO}_{2}$ production rate $(580$ to 990 mMole $\cdot \mathrm{m}^{-2} \cdot \mathrm{y}^{-1}$ ) that the sediment cannot meet this nutrient demand at all. There has been some dispute whether macrophytes take their nutrients and especially $\mathrm{IPO}_{4}$, from the sediments or from the overlying seawater (e.g. CARRIGAN \& KALFF, 1980; 1982; MCRoY et al., 1972). The results of the present study strongly suggest that the major part of the $\mathrm{NH}_{4}^{+}$and $\mathrm{\Sigma PO}_{4}$ uptake by Zostera noltii must have taken place from the overlying seawater.

Below the zone of nutrient uptake a slight but steady increase in $\mathrm{NH}_{4}^{+}$and $\mathrm{SPO}_{4}$ concentration was observed. However, the upwardly directed diffusive flux to the surface layers, calculated by Fick's law, was small, 1 to $3 \mathrm{mMole} \cdot \mathrm{m}^{-2} \cdot \mathrm{y}^{-1}$ for $\mathrm{NH}_{4}^{+}$and 0.1 to $0.3 \mathrm{mMole} \cdot \mathrm{m}^{-2} \cdot \mathrm{y}^{-1}$ for $\Sigma \mathrm{PO}_{4}$.
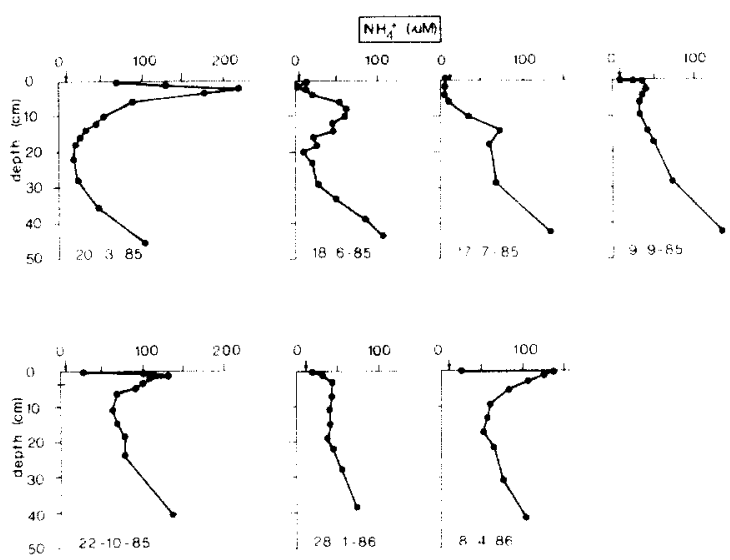

Fig. 5. Seasonal variations in pore-water ammonium concentrations.

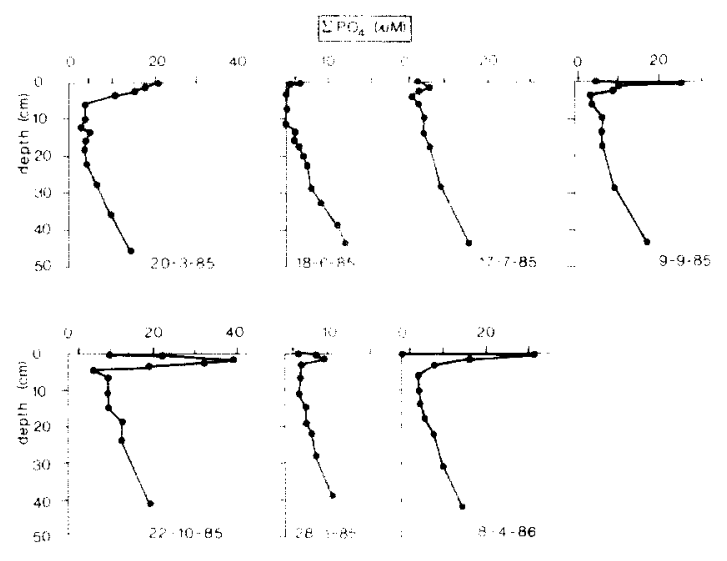

Fig. 6. Seasonal variations in pore-water ortho-phosphate concentrations. 
Mineralization processes, and nutrient uptake by Zostera noltii and sediment-seawater exchange (e.g. CALLENDER \& HAMMOND, 1982; ELDERFIELD et al., 1981b) have selectively depleted the sediment. Thus the $\mathrm{C} / \mathrm{N}$ ratio in the sediment is high $(19 \pm 1.6)$, because protein-rich organic matter is oxidized preferentially (ROSENFELD, 1981). Results of the phosphoros fractionation (Fig. 3) indicate that only small amounts are exchangeable and carbonate bound- $\mathrm{P}\left(\mathrm{NH}_{4} \mathrm{Cl}\right.$ soluble $\left.\mathrm{P}: 10-15 \%\right)$ and iron and aluminium oxyhydroxide bound- $\mathrm{P}(\mathrm{NaOH}$ soluble $\mathrm{P}$ : 10-15\%). Apatites $(\mathrm{HCl}$ soluble $\mathrm{P})$ are the dominant $(70-80 \%)$ phosphorus containing compounds. This is in reasonable agreement with the result of the calculated saturation state of the pore waters; the ion activity products (IAPs) were calculated with a modified version of the Wateq programme (VAN GAANS, 1988; TRUESDELL \& JONES, 1974). Effects of ionic strength $(I=0.55)$, ion pairing and temperature $\left(5\right.$ to $20^{\circ} \mathrm{C}$ ) were included in these calculations. The necessary $\mathrm{Ca}^{2+}, \mathrm{Mg}^{2+}, \mathrm{Na}^{+}$and $\mathrm{K}^{+}$concentrations were calculated from the measured chloride concentrations and the ratio between these cations and $\mathrm{Cl}^{-}$ in standard seawater (STUMM \& MORGAN, 1981).

The pore waters were highly supersaturated with respect to hydroxy-apatite, and undersaturated with respect to iron(3)phosphate (e.g. strengite) and also to iron(2)phosphate (vivianite). Thus iron oxydroxide bound phosphates are unstable in this reducing sediment and were probalby already liberated during the initial diagnesis (e.g. KROM \& BERNER, 1981).

\subsection{SILICA DIAGENESIS}

Dissolved reactive silica concentrations increased exponentially with depth (Fig. 4C). This increase was the result of competition between dissolution, mainly of skeletal remains of diatoms, reprecipitation processes (HURD, 1972; 1973) and sediment-seawater exchange. The apparent equilibrium concentration $\left(C_{\infty}\right)$ in summer was approximately $150 \mu \mathrm{M}$ higher than in winter because of the temperaturedependance of the dissolution process (HURD, 1972). The dissolution rate is generally considered to be proportional to the degree of undersaturation: $R=k\left(C_{\infty}-C_{X}\right) \quad$ (HURD, 1973; LERMAN, 1979). Estimates of the rate constant $k$ were obtained by fitting the following equation to the measured summer and winter profiles (LERMAN, 1979):

$$
C_{X}=C_{\infty}-\left(C_{\infty}-C_{o}\right) \exp \left\{-x\left(k / D_{s}\right)^{0.5\}}\right.
$$

assuming "quasi-steady-state" conditions during summer and winter. The diffusion coefficient, corrected for porosity and tortuosity $\left(4.7 \cdot 10^{-6} \cdot \mathrm{cm}^{-2} \cdot \mathrm{s}^{-1}\right.$ in summer and $3.4 \cdot 10^{-6} \cdot \mathrm{cm}^{2} \cdot \mathrm{s}^{-1}$ in winter) was calculated from (4) and data from the literature (WOLLAST \& GARRELS, 1971). The best fits of (7) yielded $k$ values of 7 to $8 \cdot 10^{-8} \cdot \mathrm{s}^{-1}$ in summer and $4-5 \cdot 10^{-8} \cdot s^{-1}$ in winter.

Diffusive fluxes of $\mathrm{H}_{4} \mathrm{SiO}_{4}$ from the sediment to the seawater, calculated from Fick's law:

$$
F=\Phi D_{s}\left(C_{\infty}-C_{0}\right)\left(k / D_{s}\right)^{0.5}
$$

varied between $0.2 \mathrm{mMole} \cdot \mathrm{m}^{-2} \cdot \mathrm{d}^{-1}$ in summer and $0.1 \mathrm{mMole} \cdot \mathrm{m}^{-2} \cdot \mathrm{d}^{-1}$ in winter. Actual fluxes to the overlying water are probably even lower, because part of the $\mathrm{H}_{4} \mathrm{SiO}_{4}$ is intercepted and consumed by benthic diatoms at the surface (RUTGERS VAN DER LOEFF et al., 1981; Van Geldermalsen, pers. comm.).

The calculated dissolution rates and fluxes are ap-

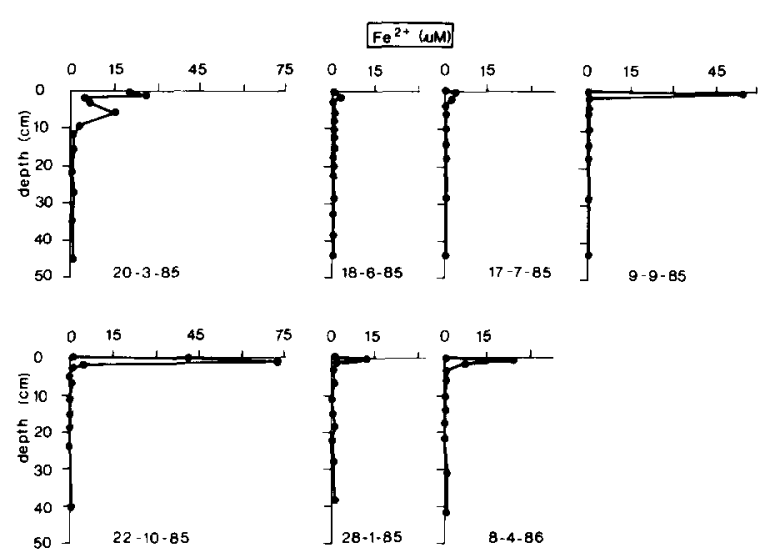

Fig. 7. Seasonal variations in pore-water iron concentrations.

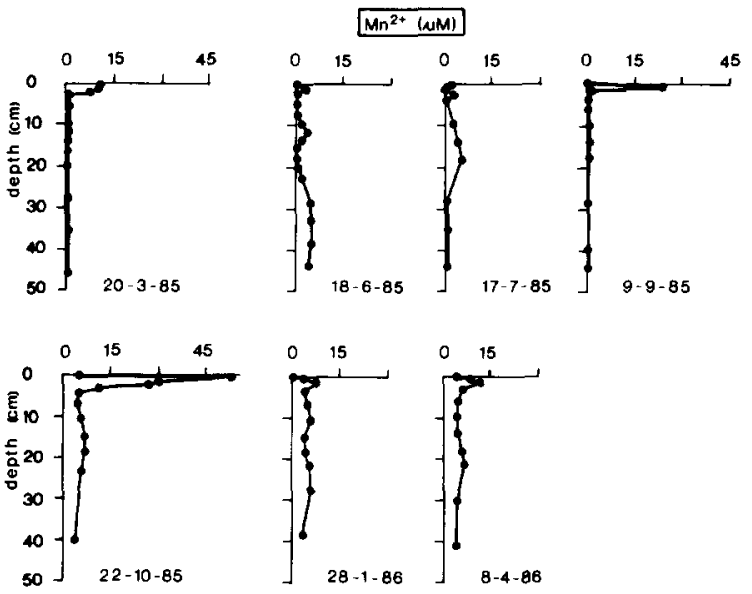

Fig. 8. Seasonal variations in pore-water manganese concentrations. 
proximately 1 order of magnitude smaller than those reported for nearshore marine sediments elsewhere (VANDERBORGHT et al., 1977; ELDERFIELD et al, 1981b; BALZER, 1984). This suggests that the solid silica in the sediment has a low reactivity. The most reactive opaline silica from diatom skeletons has already been dissolved.

\subsection{IRON AND MANGANESE DIAGENESIS}

Dissolved iron and manganese profiles (Figs 7 and 8 ) are similar to those reported for other nearshore marine sdiments by ALLER (1980) and HOLDREN et al. (1975). Distinct maxima were observed in the upper 1 to $2 \mathrm{~cm}$ and very low concentrations at greater depths.

The absence of a sub-surface maximum in June and July coincided with the $\mathrm{NH}_{4}^{+}$and $\mathrm{SPO}_{4}$ depletion in the surface layers during the summer. This suggests that the dissolved $\mathrm{Fe}^{2+}$ and $\mathrm{Mn}^{2+}$ removal from the pore waters was caused by precipitation of oxyhydroxides due to release of oxygen from the roots of Zostera noltii (see e.g. SAND-JENSEN et al., 1982). However, no visible iron oxyhydroxide precipitate on the roots or any significant change in redox conditions were observed in the top $5 \mathrm{~cm}$ during the summer.

Downcore $\mathrm{Fe}^{2+}$ concentrations in the subrecent sediment of the investigated site and in the recent fine-grained sediments elsewhere in the Eastern Scheldt (OENEMA, 1988) are equally low, while downcore $\mathrm{Mn}^{2+}$ concentrations in the subrecent sediment are 10 to 100 times lower than in the recent sediments. There are two possible explanations for low dissolved $\mathrm{Fe}^{2+}$ and $\mathrm{Mn}^{2+}$ concentrations in anoxic pore waters:

-1. a low rate of $\mathrm{Fe}$ - and $\mathrm{Mn}$ oxyhydroxide reduction, -2. precipitation of $\mathrm{Fe}-$ and $\mathrm{Mn}$ sulfides, phosphates and carbonates.

The reduction rate of $\mathrm{Fe}$ - and $\mathrm{Mn}$ oxyhydroxides in the subrecent sediment is severely limited, not only by their own low concentration but also by the low concentrations of metabolizable organic matter, which restricts the growth of heterotrophic microbes in the sediment. The likelihood of a dissolved $\mathrm{Fe}^{2+}$ and $\mathrm{Mn}^{2+}$ control by low concentration of $\mathrm{Fe}-$ and $\mathrm{Mn}$ oxyhydroxides and possibly by $\mathrm{Fe}^{2+}$ and $\mathrm{Mn}^{2+}$ precipitation is discussed in the following.

The calculated saturation indices indicate that the pore waters were close to saturation with greigite $\left(\mathrm{Fe}_{3} \mathrm{~S}_{4}\right)$ and mackinawite ( $\mathrm{FeS}$ ), with $\mathrm{pK}_{\mathrm{SP}}$ values of 4.2 and 3.7, respectively (BERNER, 1967), and undersaturated with respect to amorphous ferrous sulphides (FeS; $\left.\quad \mathrm{pK}_{\mathrm{SP}}=2.9\right), \quad$ vivianite
$\left(\mathrm{Fe}_{3}\left(\mathrm{PO}_{4}\right)_{2} \cdot 8 \mathrm{H}_{2} \mathrm{O}\right)$ and siderite $\left(\mathrm{FeCO}_{3}\right)$. This suggests that precipitation of greigite and possibly mackinawite is involved in the control of dissolved iron. Dissolved $\Sigma S$ concentrations were low $(<5 \mu \mathrm{M})$ in the upper 3 to $5 \mathrm{~cm}$, but increased to maxima of $300-400 \mu \mathrm{M}$ at 20 to $40 \mathrm{~cm}$ in the bluish-grey sediment. Pyrite $\left(\mathrm{FeS}_{2}\right)$ is the ultimate sink of the reduced $\mathrm{Fe}$ and $\mathrm{IS}$ species in marine sediments (BERNER, 1970). $\mathrm{FeS}_{2}$ concentrations varied between 0.4 and $1.1 \%$ (Fig. 3) and were linearly related to the organic carbon concentrations. Low concentrations of easily extractable iron $(0.2$ to $0.5 \% \mathrm{Fe})$ did not seem to control further pyrite formation, because the degree of pyritization (BERNER, 1970) of the easily extractable iron pool was only $54 \pm 9 \%$. In conclusion, the dissolved $\mathrm{Fe}^{2+}$ concentrations in the anoxic pore waters were most probably controlled by the precipitation of iron sulfides.

The pore waters were strongly undersaturated ( 1 to 3 orders of magnitude) with respect to pure manganese minerals such as rhodochrosite $\left(\mathrm{MnCO}_{3} ; \quad \mathrm{pK}_{\mathrm{SP}}=10.4\right.$ MIDDELBURG et al., 1987), alabandite (Mns; $p K_{S P}=1.32$, MILLS, 1974) and reddingite $\left(\mathrm{Mn}_{3}\left(\mathrm{PO}_{4}\right)_{2} ; \mathrm{pK}\right.$ SP $=31.8$, POSTMA, 1981). This indicates that precipitation of these pure phases did not control the $\mathrm{Mn}^{2+}$ concentration in the pore waters.

Approximately 20 to $30 \%$ of the total solid $\mathrm{Mn}$ concentration (Fig. 3) was oxalate-extractable (50 to 100 $\left.\mu \mathrm{g} \cdot \mathrm{g}^{-1}\right)$. Equal quantities were extracted by an unbuffered $1 \mathrm{M} \mathrm{NH}_{4} \mathrm{Cl}$ solution. It was found that $\mathrm{NH}_{4}^{+}$-oxalate as well as $\mathrm{NH}_{4} \mathrm{Cl}$ completely dissolved calcite, but according to GAMBrELL \& PATRICK (1982) only $\mathrm{NH}_{4}^{+}$-oxalate may dissolve manganese oxides to any great extent. This suggests that the extractable $\mathrm{Mn}$ in the sediment was predominantly carbonate-bound $\mathrm{Mn}$, and that manganese reduction rates were severely slowed down by the very low concentration of Mn-oxides. The large differences between downcore $\mathrm{Mn}^{2+}$ concentrations in the pore waters of the investigated subrecent sediments and those in the recent fine-grained sediments elsewhere in the Eastern Scheldt are attributable to the very low manganese reduction rates in the subrecent sediments. The easily extractable manganese in the subrecent sediment (250 to $300 \mu \mathrm{g} \cdot \mathrm{g}^{-1}$, Table 3) is probably present as a $\mathrm{Mn}, \mathrm{Ca}$ carbonate with an estimated $\mathrm{Mn}$ mole fraction of $1 \cdot 10^{-3}$. Precipitation of such $\mathrm{Mn}_{0.001}, \mathrm{Ca}_{0.999} \mathrm{CO}_{3}$ solid solutions may regulate downcore $\mathrm{Mn}^{2+}$ concentrations at 1 to $5 \mu \mathrm{M}$ in marine sediments with $\mathrm{pH}$ values of 7.2 to 7.4 and 4 to $8 \mathrm{mM} \mathrm{\Sigma CO}_{2}$ (MIDDELBURG et al., 1987), as found in the sediment investigated.

in the surface $2 \mathrm{~cm}$, freshly deposited manganese 
oxides and organic matter (e.g. from diatoms and Zostera noltii) may become incorporated in the sediment by burrowing Cerastoderma edule. This promotes a rapid microbial manganese reduction, and consequently high dissolved $\mathrm{Mn}^{2+}$ concentrations appeared in the surface pore waters (e.g. SUNDBY \& SILVERBERG, 1985).

\section{CONCLUSIONS}

The pore-water sampler proved to be useful for monitoring seasonal variations in the pore-water composition, because spatial variability as a disturbing factor could be ruled out. The use of this sampler is advised for unconsolidated sediments in salt marshes, intertidal flats and other shallow $(<0.5 \mathrm{~m})$ water bodies.

Subrecent Dunkirk deposits, exposed on intertidal flats in the Eastern Scheldt, contain predominantly non-metabolizable organic carbon. Consequently, rates of organic carbon mineralization and nutrient regeneration in these sediments are low underneath the superficial 0 to $2 \mathrm{~cm}$ of sediment in which metabolizable organic matter may temporarily accumulate. The contribution of these sediments to the carbon and nutrient dynamics in the Eastern Scheldt is negligible, because of its restricted surface area and its refractory organic matter. The organic carbon from these types of sediments, after erosion, will behave as inert stuffing in the recent fine-grained deposits, accumulating elsewhere in the Eastern Scheldt.

The dissolved $\mathrm{NH}_{4}^{+}$and $\Sigma \mathrm{PO}_{4}$ concentrations in the pore waters were controlled by mineralization, nutrient uptake by Zostera noltii and sedimentseawater exchange. Only a small percentage of the total nutrient uptake by Zostera noltii was derived from the sediment. The major part was taken up from the overlying seawater. Root-respiration probably accounted for a large part of the total dissolved inorganic carbon in the summer pore waters.

Total nitrogen, phosphorus and manganese concentrations in the sediment were low; mineralization and sediment-seawater exchange must have depleted these deposits during earlier stages of diagenesis. The low downcore $\mathrm{Mn}^{2+}$ concentrations, if compared to recent fine-grained sediments, must be attributed to the very low manganese oxide concentration and the low reduction rate in the subrecent sediment. Equilibrium with a $\mathrm{Mn}, \mathrm{Ca}$ carbonate with an estimated manganese mole fraction of $1 \cdot 10^{-3}$ apparently controlled the pore water $\mathrm{Mn}^{2+}$ concentration at 1 to $5 \mu \mathrm{m}$.

\section{REFERENCES}

ALLER, R.C., 1980. Diagenetic processes near the sediment-water interface of Long Island Sound. II Fe and Mn.-Adv. in Geoph. 22: 351-415.

ARMSTRONG, F.A.J., C.R. STERNS \& J.D.H. StrickLAND, 1967. The measurements of upwelling and subsequent biological processes by means of the Technicon autoanalyzer and associated equipment.-Deep-Sea Res. 14: 381-389.

BALZER, W., 1984. Organic matter degradation and biogenic element cycling in a nearshore sediment (Kiel Bight).-Limnol. Oceanogr. 29: 1213-1246.

Begheyn, L.TH., N. VAN BREemen \& E.J. Velthorst, 1978. Analysis of sulfur compounds in acid sulfate soils and other recent marine soils.-Comm. in Soil Sci. and Plant Anal. 9: 873-882.

BERNER, R.A., 1967. Thermodynamic stability of sedimentary iron sulfides.-Am. J. Sci. 265: 773-785.

-—, 1970. Sedimentary pyrite formation.-Am. J. Sci. 268: $1-23$.

- - 1980. Early Diagenesis; a theoretical approach. Princeton University Press, Princeton, N.J.

BERNER, R.A. \& J.T. WESTRICH, 1985. Bioturbation and the early diagenesis of carbon and sulfur--Am. J. Sci. 285: 193-206.

BERG, J.H. VAN DEN, 1986. Aspects of sediment- and morphodynamics of subtidal deposits of the Oosterschelde (The Netherlands).-Rijkswaterstaat comm. 43, The Hague.

BREWER, P.J. \& J.P. RILEY, 1966. The automatic determination of silicate-silicon in natural waters with special reference to seawater-Anal. chim. Acta 51: 514-519.

BRUIN, M.P. DE \& M.H. WILDEROM, 1961. Tussen afsluitdijken en deltadijken; Noord-Beveland, geschiedenis van strijd, nederlaag en overwinning op het waterLittoy \& Olthoff, Middelburg: $304 \mathrm{p}$.

Callender, E. \& D.E. Hammond, 1982. Nutrient exchange across the sediment-water interface in the Pontomac river estuary.-Eastuar. coast. mar. Sci. 15: 395-413.

CARRIGAN, R., 1980. Interstitial water sampling by dialysis: Methodological notes.-Limnol. Oceanogr. 29: 667-670.

Carrigan, R. \& J. KalfF, 1980. Phosphorus sources for aquatic weeds; water or sediments.-Science 207: 987-989.

1982. Phosphorus release by submerged macrophytes; significance to epiphytes and phytoplankton.-Limnol. Oceanogr. 27: 419-427.

DAMEN, E.A.M.J., 1979. Verspreiding en biomassa van Zostera marina L. en Zostera noltii Hornem in the Oosterschelde.-DIHO-report D6-1979, Yerseke.

DEW, P.M. \& J.E. WALSH, 1981. A set of library routines for solving parabolic equations in one space variable. ACM Trans. Math. Software 7: 295-314.

Elderfield, H., R.J. McCAfFRey, N. LuedtKe, M. Bender \& V.W. TRUESDALE, 1981a. Chemical diagenesis in Narragansett Bay.-Am. J. Sci. 281: 1021-1055.

Elderfield, H., N. LUedtKe, R.J. McCaffrey \& M. BENDER, 1981b. Benthic flux studies in Naragansett Bay.-Am. J. Sci. 281: 768-787.

GAANS, P.F.M. VAN, 1988. WateqX restructured, generalised and extended Fortran 77 computer code and data 
base format for the Wateq aquaeous chemical model for element speciation and mineral saturation, for use on personal computers or main frame (submitt.).

GambrelL, R.P. \& W.H. PATRick JR., 1982. Manganese. In: PAGE et al. Methods of soil analysis.-Am. Soc. Agr. Wisconsin: 313-322.

GLEASON, M.L. \& J.C. ZIEMAN, 1981. Influence of tidal inundation on internal oxygen supply of Spartina alterniflora and Spartina patens.-Estuar. coast. Shelf Sci. 13: 47-57.

GrasshofF, W. \& H.P. HANSEN, 1979. Über ein Schleppsystem zur kontinuirlichen Erfassung chemischer Parameter vom fahrenden Schiff in Tiefen bis zu 100 Meter--Vom Wasser 5: 73-83.

GILBOA-BARBER, N., 1971. Direct spectrophotometric determination of inorganic sulfide in biological materials and in other complex mixtures.-Anal. Biochem. 43: 129-133.

Goldhaber, M.B., R.C. Aller, J.K. Cochran, J.K. Rosenfeld, C.S. MARTENS \& R.A. Berner, 1977. Sulfate reduction, diffusion and bioturbation in Long Island Sound sediments: Report of the FOAM group.-Am. J. Sci. 277: 193-237.

HENRIKSEN, A., 1966. An automated modified formaldoxime method for determining low concentrations of manganese in water containing iron.-Analyst 91: 647-651

- - 1967. Automatic method for the determination of iron.-Vattenhygièn, May 22. 1967: 1-8.

HessLeIN, R.H., 1976. An in situ sampler for close interval pore water studies.-Limnol. Oceanogr. 21: 912-914.

HIELTJES, A.H.M. \& L. LYKLEMA, 1980. Fractionation of inorganic phosphates in calcareous sediments.-J. Environm. Qual. 9: 405-407.

HOLDREN, G.R., O.P. BRICKER \& G. MATISOF, 1975. A model for the control of dissolved manganes in the interstitial waters of Chesapeake Bay. In: T.M. CHURCH. Marine chemistry in coastal environments. Am. Chem Soc. Washington: 364-381.

HOWES, B.L., 1985. Effects of sampling technique on measurements of pore water constituents in salt marshes.-Limnol. Oceanogr. 30: 221-227.

HURD, D.C., 1972. Factors affecting the solution rate of biogenic opal in seawater.-Earth Planet. Sci. Lett. 15: 411-417.

1973. Interactions of biogenic opal, sediment and seawater in the Central Equatorial Pacific.-Geochim. cosmochim. Acta 37: 2257-2282.

J $\emptyset$ RGENSEN, B.B., 1977. The sulfur cycle of a coastal marine sediment (Limfjorden, Denmark).-Limnol. Oceanogr. 22: 814-832.

Kepkay, P.E., R.C. CoOKe \& A.J. Bowen, 1981. Molecular diffusion and the sedimentary environment: results from the in situ determination of whole sediment diffusion coefficients.-Geochim. cosmochim. Acta 45: 1401-1409.

KNOESTER, M., J. VISSER, B.A. BANNINK, C.J. COLIJN \& W.P.A. BROEDERS, 1984. The Eastern Scheldt project.-Wat. Sci. Tech. 16: 51-77.

KRoM, M.D. \& R.A. BERNER, 1981. The diagenesis of phosphorus in a nearshore marine sediment.Geochim. cosmochim. Acta 45: 207-216.

LERMAN, A., 1979. Geochemical processes in water and sediment environments. Wiley, New York: 1-481.

LI, Y.H. \& S. GREGoRY, 1974. Diffusion of ions in seawater and in deep-sea sediments.-Geochim. cosmochim. Acta 38: 703-714.

LORD, C.J. \& T.M. CHURCH, 1983. The geochemistry of salt marshes: sedimentary ion diffusion, sulfate reduction and pyritization.-Geochim. cosmochim. Acta 47: $1381-1391$

McRoY, C.P., R.J. BARSDATE \& M. NEBERT, 1972. Phosphorous cycling in an eelgrass (Zostera marina) ecosystem.-Limnol. Oceanogr. 17: 58-67.

MERKS, A.G.A. \& J.J. SINKE, 1981. Application of an automated method for dissolved sulfate analysis to marine and brackish waters.-Mar. Chem. 10: 103-108.

Middelburg, J.J., G.J. de LANGe \& C.H. VAN DeR Weyden, 1987. Manganese solubility control in marine porewaters.-Geochim. cosmochim. Acta 51: 759-763.

MILLS, K.C., 1974. Thermodynamic data for inorganic sulfides, selenides, and tellurides. Butterworths, London.

MURPHY, J. \& J.P. RILEY, 1962. A modified single solution method for the determination of phosphate in natural waters.-Anal. Chim. Acta 27: 31-36.

NiENHUIS, P.H. \& E.A.M.J. DAEMEN, 1985. De biomassa en productie van het fytobenthos. In: P.B.M. STORTELDER. De koolstofbalans in de Oosterschelde. Interimrapport, nota 1985-11. Middelburg

OENEMA, O, 1988. Early diagenesis in recent fine-grained sediments in the Eastern Scheldt, Southwest Netherlands. Ph. D. thesis, Univ. Utrecht: 1-223.

PAGE, A.L., R.H. MILLER \& D.R. KeENEY, 1982. Methods of soil analysis. Part 2. 2nd ed. Agronomy no. 9. SSSA inc. Madison, Wisconsin: 1-1159.

POSTMA, D., 1981. Formation of siderite and vivianite and the pore-water composition of a recent bog sediment in Denmark.-Chem. Geol. 31: 225-244.

Redfield, A.C., B.H. KetCHEM \& F.A. Richards, 1963. The influence of organisms on the composition of seawater. In: M.H. HiLL. The Sea; ideas and observations. Vol. 2. Interscience, New York: 26-77.

ROSENFELD, J.K., 1981. Nitrogen diagenesis in Long Island Sound sediments.-Am. J. Sci. 281: 436-463.

RUTGERS VAN DER LOEFF, M.M., 1981. Wave effects on sediment-water exchange in a submerged sand bed-Neth. J. Sea Res. 15: 100-112.

Rutgers VAN DER LOEFF, M.M., F.B. VAN ES, W. HELDER \& R.T.P. DE VAIES, 1981. Sediment water exchanges of nutrients and oxygen on tidal flats in the Ems-Dollard estuary.-Neth. J. Sea Res. 15: 113-129.

Sand-Jensen, K, C. Prahl \& H. Stokholm, 1982. Oxygen release from roots of submerged aquatic macrophytes.-Oikos 38: 349-354.

SØRENSEN, J. \& B.B. JøRGENSEN, 1987. Early diagenesis in sediments from Danish coastal waters: microbial activity and Mn-Fe-S geochemistry.-Geochim. cosmochim. Acta 51: 1583-1590.

SCHWERTMANN, U., 1964. Differenzierung der Eisenoxide des Bodens durch photochemische Extraktion mit saurer Ammoniumoxalat-losung. $-Z$. Pflanzenernaehr., Dueng., Bodenk. 108: 37-45.

StORTELdER, P.M.B., J.S.L. VINK \& P.F. HAVERMANS, 1984. Waterkwaliteitskenmerken van de Oosterschelde en 
Schelde-Rijn verbinding.-Nota DDMI: 83-13 Middelburg.

StumM, W. \& J.J. MORGaN, 1981. Aquatic chemistry. John Wiley, New York: $780 p$.

SundBY, B. \& N. SilverberG, 1985. Manganese fluxes in the benthic boundary layer--Limnol. Oceanogr. 30: 372-381.

TELLOW, J.A. \& A.L. WILSON, 1964. Method for determining ammonium in boiler feed water-Analyst, 84: 453-465.

TRUESDELL, A.H. \& B.F. JONES, 1974. WATEQ, a computer programme for calculating chemical equilibrium in natural waters.-U.S. Geol. Surv., J. Res. 2: 233-248.

ULLMANN, W.J. \& R.C. ALLER, 1982. Diffusion coefficients in nearshore marine sediments.-Limnol. Oceanogr. 27: 552-556.

VANDERBORGHT, J., R. WOLLAST \& G. BILLEN, 1977. Kinetic models of diagenesis in disturbed sediments: 1. Mass transfer properties and silica diagenesis.-Limnol. Oceanogr. 22: 787-793.

WOLLAST, R. \& R.M. GARRELS, 1971. Diffusion coefficients of silica in seawater.-Nature 229: 94.

ZALL, D.M., D. FISHER \& M.D. GaRNER, 1956. Photometric determination of chlorides in water-Anal. Chem. 28: 1665-1668.

(received 12 January 1988; revised 28 July 1988) 